\title{
Physicochemical, antioxidant and microbial properties of crystallized pansies (Viola $\times$ wittrockiana) during storage
}

\author{
Luana Fernandes ${ }^{1,2,3}$, Susana Casal ${ }^{2}$, José A Pereira ${ }^{1}$, \\ Ermelinda L Pereira ${ }^{1}$, Jorge A Saraiva ${ }^{3}$ and Elsa Ramalhosa ${ }^{1}$
}

\begin{abstract}
Edible flowers, such as pansies, have a short shelf-life. Crystallization is a treatment used to prolong the shelflife of fruits and vegetables. So, the aim of the present work was to investigate the effect of crystallization in the physicochemical, microbial and antioxidant properties of pansies (Viola $\times$ wittrockiana) during room temperature storage $(7,15,30,60$ and 90 days). Comparing fresh and crystallized pansies, significant differences were detected. After 90 days of storage, crystallized pansies kept similar appearance to those immediately after treatment. A significant decrease in water activity, moisture, ash and protein contents was observed between 0 and 90 days of storage for crystallized pansies. Some bioactive compounds, such as flavonoids and monomeric anthocyanins, showed a significant decrease after 90 days of storage, while hydrolysable tannins increased. Concerning phenolic compounds, these maintained constant along storage. The microbial load of crystallized pansies during all storage time was lower than fresh ones. So, crystallization can be an effective method for pansies preservation, being some nutritional and bioactive compounds, little affected during storage. However, crystallization contributed to a high increase in sugar content and energy values compared to fresh pansies.
\end{abstract}

\section{Keywords}

Edible flowers, crystallization, bioactive compounds, antioxidant activity, nutritional composition, microbial quality, storage

Date received: 5 November 2018; accepted: 1 February 2019

\section{INTRODUCTION}

Garden pansies (Viola $\times$ wittrockiana) are edible flowers that have been used for years in cooking or as decoration in several dishes. Their flavour and colour make them special, not only for their fresh consumption, but also as an ingredient in salads and to garnish desserts (frosted cakes, sorbets and iced drinks). Pansies are perfect cool-season edible flowers, so they will grow in winter and again in spring. In order to have flowers' products available for the food industry all around the year, new technologies must be tested and applied to

Food Science and Technology International 0(0) 1-8

(C) The Author(s) 2019 Article reuse guidelines:

sagepub.com/journals-permissions

DOI: $10.1177 / 1082013219833234$

journals.sagepub.com/home/fst

๑SAGE edible flowers. The market of this product is not only interested in fresh products but also in processed flowers' products, which should maintain the sensory properties as unaltered as possible. In this sense, a process that originates good quality flowers' products could be an option to increase their market share. The most frequently applied processes to preserve pansies include

\footnotetext{
${ }^{1}$ Centro de Investigação de Montanha (CIMO)/School of Agriculture, Polytechnic Institute of Bragança, Bragança, Portugal 2LAQV@REQUIMTE/Laboratory of Bromatology and Hydrology, Faculty of Pharmacy, Porto University, Porto, Portugal

${ }^{3}$ Organic Chemistry, Natural Products and Agrifood (QOPNA) Chemistry Department, University of Aveiro, Aveiro, Portugal

Corresponding author:

Elsa Ramalhosa, Mountain Research Centre (CIMO), Campus de $\mathrm{St}^{\mathrm{a}}$ Apolónia, Bragança 5300-253, Portugal.

Email: elsa@ipb.pt
} 
refrigeration, drying and preservation in distillates. Nevertheless, these technologies have undesirable effects, namely changes in texture and colour, nonfresh flavour with a loss of nutritive value, which reduces its economic importance.

Crystallization is a technology that consists of placing fresh or frozen raw materials in a hypertonic solution prepared from sugars, most often from sucrose and glucose (Barat et al., 2002; Korel and Balaban 2006; Witczak et al., 2017). In particular, crystallized flowers consist in coating a flower with egg white (pasteurized), followed by dipping and rolling the flower in a sugar solution, and then sprinkling the upper surface of the flower again with sugar (Clemons, 2006). Crystallization is described as a technology able to extend the shelf-life (due to dehydration); to maintain appropriate taste and nutritive value; and to retain the firmness, the natural aroma and colour of the fresh product (Witczak et al., 2017). However, until now this technology was mostly applied to fruits, such as orange peel (Witczak et al., 2017), chestnuts (Korel and Balaban, 2006), pineapple (Barat et al., 2002) and plums (Nunes et al., 2008). Some cookbooks mention recipes for this method to be applied to edible flowers (Creasy, 2012; Dupree, 2004; McGee, 2010). Crystallized flowers are fantastic for decorating cakes or desserts and to accompany any sweet dish. Nowadays, there are some companies that sell crystallized flowers, such as Candiflor in Toulouse, Marx Pantry in US, Fresh Origins in California, Eat My Flowers in United Kingdom, Meadowsweet flowers in England and Ervas Finas in Portugal. Of our knowledge, until now there is no available scientific literature about the effect of crystallization on quality and shelflife of pansies. In this order, the objective of this study was to evaluate, for the first time, the effect of crystallization on the quality of pansies during 90 days of storage under room temperature. The quality of pansies was evaluated in relation to some physicochemical characteristics, namely visual appearance, water activity $\left(a_{\mathrm{w}}\right)$ and weight loss (WL), as well as bioactive compounds (total reducing capacity (TRC), flavonoids, monomeric anthocyanins and hydrolysable tannins) and antioxidant activity (2,2-diphenyl-1-picrylhydrazyl (DPPH) radical scavenging activity and reducing power). Furthermore, the nutritional and microbial qualities were also evaluated.

\section{MATERIAL AND METHODS}

\section{Samples}

Fresh white pansies (Viola $\times$ wittrockiana) were collected in full ripening state at the greenhouse of School of Agriculture, Polytechnic Institute of Bragança (Bragança, Portugal). After harvest, fresh flowers were immediately transported to the laboratory under refrigeration.

\section{Crystallization}

Crystallization treatment was applied according to some cookbooks. Pansies were painted with egg white (pasteurized) on the front and back of flowers, using a fine brush. Then they were sprinkled with sugar evenly over the wet petals and placed face down on paper. Previously, the immersion of pansies in a sucrose solution was tested, but the flowers became wrinkled and with a fragile texture. Crystalized flowers were maintained under refrigeration $\left(4^{\circ} \mathrm{C}\right)$ for about $48 \mathrm{~h}$. The average value of weight gain of crystalized pansies was $5.5 \pm 1.1$ times the flower's weight before treatment.

\section{Storage}

Crystallized pansies were stored under room temperature $\left(20^{\circ} \mathrm{C}\right)$, during 90 days. After 7, 15, 30, 60 and 90 days of storage, photos of the flowers were taken and the physicochemical composition, bioactivity and antioxidant activity were measured, as detailed below. After storage the samples were frozen and freezedried (Coolsafe, Lynge, Denmark) to perform the chemical analyses, while for microbial quality evaluation the samples in fresh state were used.

\section{Water activity and WL}

Water activity $\left(a_{w}\right)$ was determined with a portable water activity meter (Novasina, LabSwift-aw, Lachen, Switzerland). Weight was measured in a digital balance (Kern ACJ/ACS, Balingen, Germany) and $W L$ was determined according to equation (1)

$$
W L=\frac{M_{0}-M}{M_{0}} \times 100
$$

where $M_{0}$ is the initial mass of crystallized pansies at day 0 and $M$ is the mass of crystallized pansies during storage. All analyses were performed in triplicate.

\section{Nutritional composition}

The nutritional composition (moisture, ash, total lipids, reducing sugars and carbohydrates) of each sample was analysed using AOAC (1990) procedures and expressed in $\mathrm{g} / 100 \mathrm{~g}$ fresh or crystallized weight ( $\mathrm{fw}$ or $\mathrm{cw}$ ), applied to fresh and crystallized pansies, respectively. All measurements were performed in triplicate. Moisture content was determined by drying the sample to a constant weight at $105^{\circ} \mathrm{C}$; ash content 
was measured by calcination at $550{ }^{\circ} \mathrm{C}$ for at least $2 \mathrm{~h}$, until achieving white ashes. Protein content of the samples was estimated by the Kjeldahl method, using a conversion factor of 6.25 , according to Sotelo et al. (2007) and Rop et al. (2012). Lipids were determined by extracting a known mass of powdered sample with petroleum ether, using a Soxhlet apparatus. Reducing sugars were determined by the dinitrosalicylic acid method. Carbohydrates were calculated according to equation (2)

$$
\begin{aligned}
& \text { Carbohydrates }\left(\frac{g}{100 g \text { fw or cw }}\right) \\
& =100-(\text { moisture }+ \text { ash }+ \text { protein }+ \text { lipids })
\end{aligned}
$$

Energy was calculated according to equation (3)

$$
\begin{aligned}
& \text { Energy }\left(\frac{k c a l}{100 g \text { fw or } c w}\right) \\
& =\left(4 \times\left[\frac{g(\text { protein })}{100 g f w \text { or } c w}+\frac{g(\text { carbohydrates })}{100 g f w \text { or } c w}\right]\right) \\
& \quad+\left(9 \times \frac{[g(\text { lipids })]}{100 g \text { fw or } c w}\right)
\end{aligned}
$$

\section{Extraction conditions for bioactivity evaluation}

The extraction conditions used were those described by Li et al. (2014), with slight modifications. Freeze-dried powder of each sample $(1 \mathrm{~g})$ was extracted with $10 \mathrm{ml}$ of water:acetone $(6: 4, \mathrm{v} / \mathrm{v})$, at $37^{\circ} \mathrm{C}$ for 30 min under agitation (900 rpm, IKA, RCT Model B, Staufen, Germany). The water:acetone extracts were filtered and placed in a rotary evaporator (Stuart, RE300DB, Stone, UK) to remove the solvent. Then, all extracts were frozen and placed in the freeze drier (Coolsafe, Lynge, Denmark) for two days. The extracts obtained were redissolved within the same solvent to a concentration of $50 \mathrm{mg}$ extract $/ \mathrm{ml}$ and covered with aluminium foil under freezing until further analysis. All extractions were performed in triplicate.

\section{Bioactive compounds}

Total monomeric anthocyanins, total flavonoids and hydrolysable tannin contents of fresh ( 0 days) and crystalized pansies $(0,7,15,30,60$ and 90 days) were determined following the methodologies used by Fernandes et al. (2018). All measurements were performed in triplicate. The results for monomeric anthocyanins were expressed in $\mu \mathrm{g}$ cyanidin-3-glucoside/g dry weight
( $\mu \mathrm{g}$ Cy 3-glu/g dw), flavonoids in $\mathrm{mg}$ of quercetin equivalent/g dry weight (mg QE/g dw) and hydrolysable tannins in $\mathrm{mg}$ of tannic acid equivalent/g dry weigh (mg TAE/g dw).

\section{TRC}

The TRC of each sample was determined by the FolinCiocalteu method described by Falcão et al. (2017). To $8 \mathrm{ml}$ of the extract solution was added $500 \mu \mathrm{l}$ of FolinCiocalteu reagent. After $3-8 \mathrm{~min}, 1.5 \mathrm{ml}$ of saturated sodium carbonate solution was added. After $2 \mathrm{~h}$ the absorbance values were read at $765 \mathrm{~nm}$. The blank and standards were prepared similarly, replacing the sample by the solvent used in the extraction and the standards, respectively. A calibration curve was obtained with gallic acid $(0.25-5 \mathrm{mg} / \mathrm{l})$ and the results expressed on $\mathrm{mg}$ gallic acid equivalent/g dry weight (mg $\mathrm{GAE} / \mathrm{g} \mathrm{dw}$ ). All measurements were performed in triplicate.

\section{Antioxidant activity}

$D P P H$ radical scavenging activity. DPPH radical scavenging activity was determined by the procedure described by Delgado et al. (2010) with some modifications. The pansy extract solutions were diluted with the solvent used for the extraction and $300 \mu \mathrm{l}$ of these solutions were added to $2.7 \mathrm{ml}$ of the DPPH methanolic solution $\left(6.09 \times 10^{-5} \mathrm{~mol} / \mathrm{l}\right)$. After $1 \mathrm{~h}$ in the dark at room temperature, the absorbance was read at $517 \mathrm{~nm}$. Antioxidant activity was expressed by the percentage of scavenging effect according to the formula in equation (4)

$$
\begin{gathered}
D P P H \text { radical scavenging effect }(\%) \\
=\frac{A_{D P P H}-A_{\text {Sample }}}{A_{D P P H}} \times 100
\end{gathered}
$$

where $A_{D P P H}$ is the absorbance of the DPPH solution and $A_{\text {Sample }}$ is the absorbance in the presence of the sample. The blank was made with the solution used in the extraction of the samples. The extract concentration providing $50 \%$ of DPPH radical scavenging effect $\left(\mathrm{EC}_{50}\right)$ was calculated from the graph of DPPH radical scavenging effect percentage versus extract concentration. All measurements were performed in triplicate.

Reducing power. The reducing powers of the extracts were determined by the procedure described by Delgado et al. (2010). To $1.0 \mathrm{ml}$ of extract solutions at different concentrations were added $2.5 \mathrm{ml}$ of phosphate buffer $0.2 \mathrm{M}(\mathrm{pH} 6.6)$ and $2.5 \mathrm{ml}$ of $\mathrm{K}_{3}\left[\mathrm{Fe}(\mathrm{CN})_{6}\right]$ $1 \%(\mathrm{~m} / \mathrm{v})$. After shaking, the mixture was incubated at 
$50{ }^{\circ} \mathrm{C}$ for $20 \mathrm{~min}$. A volume of $2.5 \mathrm{ml}$ of $10 \%$ trichloroacetic acid $(\mathrm{m} / \mathrm{v})$ was added with further stirring. A volume of $2.5 \mathrm{ml}$ of the mixture was transferred to another test tube, to which $2.5 \mathrm{ml}$ of distilled water and $0.5 \mathrm{ml}$ of $\mathrm{FeCl}_{3} 0.1 \%(\mathrm{~m} / \mathrm{v})$ were added. The absorbance values were read at $700 \mathrm{~nm}$. From the graph $\mathrm{Abs}_{700 \mathrm{~nm}}$ versus concentration, the $\mathrm{EC}_{50}$ values were determined corresponding to the concentration that resulted in an absorbance value of 0.5 . All measurements were performed in triplicate.

\section{Microbial quality}

In fresh and crystallized pansies (0 days), as well as crystallized pansies after storage ( 7 and 90 days), the total aerobic mesophilic, yeast, moulds, total coliforms, Escherichia coli and psychrotrophic bacteria counts were determined. Five grams of sample was diluted in $45 \mathrm{ml}$ of glycerol $(20 \%)$. Samples were placed in sterile stomacher bags and homogenized in a Stomacher 400 (Seward, UK) for $2 \mathrm{~min}$. The homogenates were subjected to serial dilutions with peptone water and then $1 \mathrm{ml}$ of each dilution was pipetted into the surface of Plate Count Agar (PCA, Merck); Dichloran Glycerol (DG-18, Merck) and Man, Rogosa and Sharpe Agar (MRS-Agar, Merck). The PCA plates were then incubated for two days at $30^{\circ} \mathrm{C}$ for total aerobic mesophilic count and five days at $10^{\circ} \mathrm{C}$ for psychrotrophic bacteria count. Yeast and moulds were determined in DG18 agar plates, incubated at $27^{\circ} \mathrm{C}$ for $3-5$ days. Total coliforms and E. coli were determined according to the SimPlate method. All counts were expressed as $\log 10 \mathrm{cfu} / \mathrm{g}$ fresh sample. All analyses were performed in triplicate.

\section{Statistical analysis}

The statistical analysis was performed on SPSS software, Version No. 18.0 (SPSS Inc., Chicago, USA). The normality of the data was verified by Shapiro-Wilk test. Analysis of variance (ANOVA) or ANOVA Welch was carried out to determine if there were significant differences $(p<0.05)$ between samples, depending on the existence or not of homogeneity of variances, respectively. Additionally, if significant differences were detected between treatments, a post hoc analysis was performed, namely Tukey's honestly significant difference test (if variances in the different groups were identical) or GamesHowell test (if they were not). The homogeneity of the variances was tested by Levene's test.

\section{RESULTS AND DISCUSSION}

\section{Visual appearance, $a_{w}$ and $W L$}

Visual appearance, $\mathrm{a}_{\mathrm{w}}$ and weight loss of fresh and crystallized flowers during storage are presented in
Figure 1 and Table 1. The visual appearance of the flowers is one of the attributes that most attracts the consumer and strongly affects the decision of buying. Furthermore, at the point of purchase, the consumer uses factors associated with appearance to provide an indication of freshness and quality. Regarding Figure 1, the crystallized flowers maintained the structural integrity of the flowers and they have similar visual appearance like the fresh ones. Only a layer of sugar was visible around the whole flower. Crystallized pansies on 7, 15, 30, 60 and 90 days showed similar appearance to that of crystallized ones at day 0 . So, storage time did not influence the visual appearance of crystallized pansies. However, looking at the data with more detail, the moisture content decreased from 1.69 to $0.28 \mathrm{~g} /$ $100 \mathrm{~g} \mathrm{cw}$ and the $\mathrm{a}_{\mathrm{w}}$ from 0.83 to 0.38 at 0 and 90 days of storage. After this period of time, the WL was only equal to $12.6 \%$. Thus, some water loss was observed, but as the sugar layer was so significant, pansies' appearance was preserved. Furthermore, in a previous study the shelf-life of fresh white pansies was determined and they only maintained good appearance until six days (Fernandes et al., 2017). So, crystallized pansies have a shelf-life 15 times longer than fresh flowers.

\section{Nutritional composition}

Data on the nutritional composition and energetic value of fresh and crystallized pansies are shown in Table 1. Fresh pansies showed the highest water activity value $(0.98)$, as well as moisture and ash contents (91.3 and $1.00 \mathrm{~g} / 100 \mathrm{~g}$ fw, respectively). Carbohydrates were the second most abundant macronutrients in fresh pansies $(5.3 \mathrm{~g} / 100 \mathrm{~g} \mathrm{fw})$, followed by proteins $(2.03 \mathrm{~g} / 100 \mathrm{~g} \mathrm{fw})$. Fresh pansies only presented $0.84 \mathrm{~g} / 100 \mathrm{~g} \mathrm{fw}$ in reducing sugars and an energetic value of $33 \mathrm{kcal} / 100 \mathrm{~g} \mathrm{fw}$, being a good food option for low-calorie diets. Similar results for fresh pansies were reported by other authors, namely moisture $(86.32 \mathrm{~g} / 100 \mathrm{~g}$ fw $)$, carbohydrates $(6.5 \mathrm{~g} / 100 \mathrm{~g} \mathrm{fw})$, proteins $(2.1 \mathrm{~g} / 100 \mathrm{~g} \mathrm{fw})$, lipids $(0.44 \mathrm{~g} / 100 \mathrm{~g} \mathrm{fw})$, ash $(1.1 \mathrm{~g} / 100 \mathrm{~g} \quad \mathrm{fw})$ and energy $(38 \mathrm{kcal} / 100 \mathrm{~g} \quad \mathrm{fw})$ (González-Barrio et al., 2018); and proteins $(0.67 \mathrm{~g} / 100 \mathrm{~g} \mathrm{fw})$ (Rop et al., 2012).

Crystallization of pansies with sucrose (0 days) decreased the water activity to 0.83 , and the moisture and ash contents to 1.69 and $0.51 \mathrm{~g} / 100 \mathrm{~g} \mathrm{cw}$, respectively, because the added sucrose decreased the water availability for microorganisms and contributed to the fresh weight, reducing the water and ash's proportion. In fact, the sugar used was refined and so its mineral content is low, explaining the observed decrease in ash content. On the contrary, the reducing sugars and carbohydrates contents in crystalized pansies ( 0 days) 
Fernandes et al.

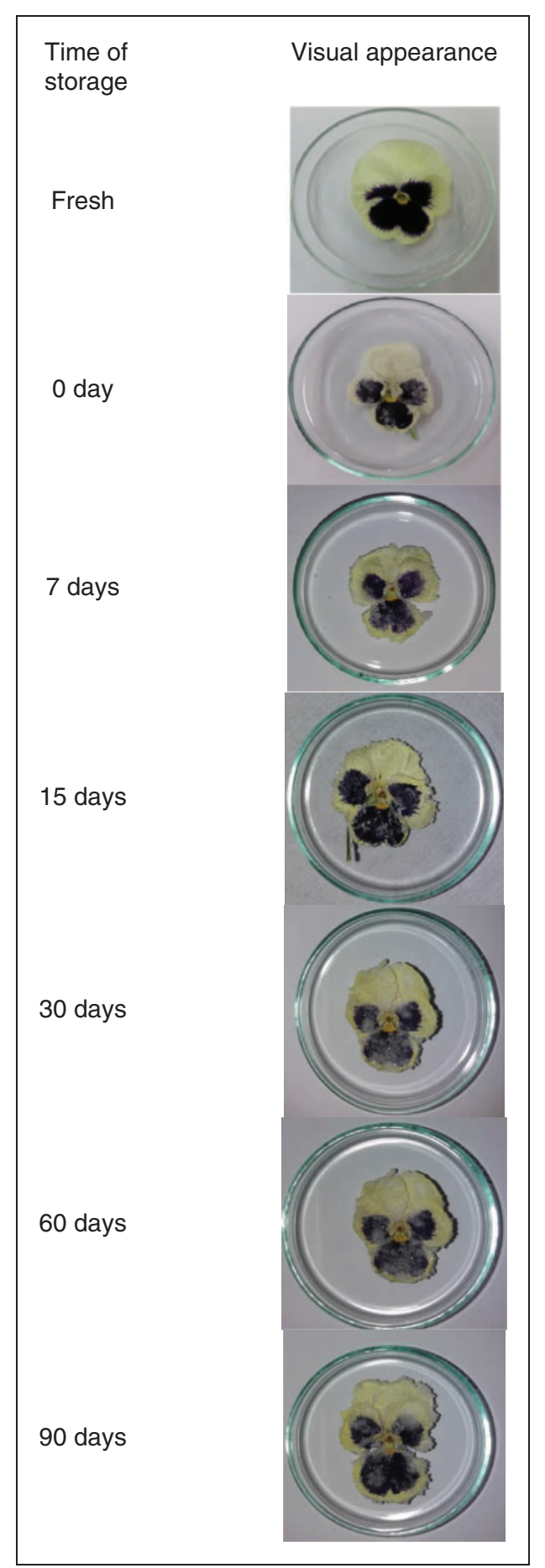

Figure 1. Visual appearance of crystallized pansies during storage.

increased to 3.99 and $92.2 \mathrm{~g} / 100 \mathrm{~g} \mathrm{cw}$, approximately 4.8 and 17 times more than in fresh (not crystalized) pansies due to the addition of sugar to pansies. One part of the sucrose may have suffered hydrolysis, liberating glucose and fructose, which are reducing sugars. Consequently, the energetic value increased 12-fold,

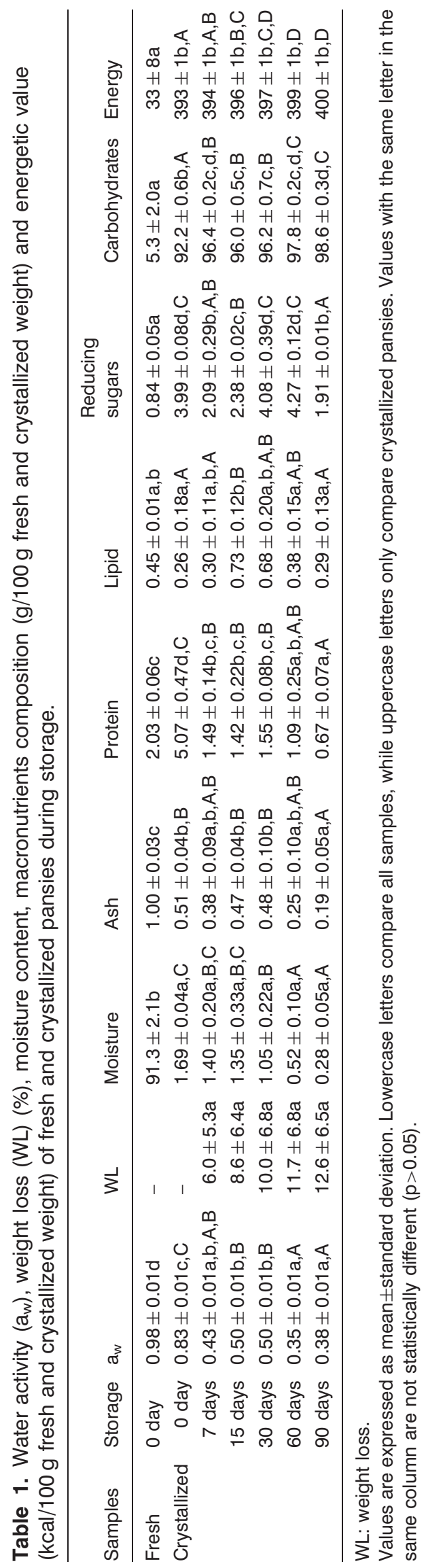


corresponding to $393 \mathrm{kcal} / 100 \mathrm{~g} \mathrm{cw}$, when compared to fresh (not crystalized) pansies.

Along storage (90 days), the moisture content decreased from 1.69 to $0.28 \mathrm{~g} / 100 \mathrm{~g} \mathrm{cw}$ because some water might have diffused out from pansies. A final water activity equal to 0.38 has been achieved, indicating that crystallized pansies were microbiologically stable. Furthermore, the lowest ash, protein and reducing sugars contents were observed after 90 days of storage, while the highest carbohydrates content and energetic value were obtained. A similar decrease in moisture content was reported for a pumpkin candy, between 20.1 and $9.3 \%$ for $0-3$ months, respectively (Muzzaffar et al., 2016). Furthermore, a decrease in ash and protein values was also observed in a tomato candy with different percentages of sugar $(40,50$ and $60 \%)$ during storage $(0,2,4$ and 6 months) (Hasanuzzaman et al., 2014). Concerning reducing sugars, Muzzaffar et al. (2016) observed an increase in these compounds from 2.9 to $3.9 \%$ at $0-3$ months, respectively, during storage, while in the present work no trend in the reducing sugars of crystallized pansies along 90 days of storage was observed.

\section{Bioactive compounds}

Table 2 shows that fresh pansies presented the highest values for all studied bioactive compounds. These results might be due to the fact that crystallized pansies had sugar around flower, which contributed to the dry weight, decreasing the bioactive compounds' concentrations. Comparing crystallized pansies during storage, statistically significant differences in bioactive compound values were detected, except in TRC (total phenols). However, a similar trend was not detected for the bioactive compounds during storage. In general, flavonoids and monomeric anthocyanins decreased along storage. This could mainly be a result of oxidation, polymerization of some phenolic compounds with proteins or to the disruption in cell structure during processing (Kim and Padilla-Zakour, 2004; VarelaSantos et al., 2012). On the contrary, hydrolysable tannins increased their values from 1.75 to $3.59 \mathrm{mg} \mathrm{TAE} / \mathrm{g}$ $\mathrm{dw}$ during 90 days of storage. Concerning the total phenols contents (TRC assay) of crystallized pansies, similar values were observed during all storage period, suggesting that crystallization conferred some degree of protection on these compounds. Different results to ours were reported by Muzzaffar et al. (2016), who detected a $10 \%$ decrease in phenolic compounds contents during storage (0-3 months) of a pumpkin candy.

\section{Antioxidant activity}

The antioxidant activity determined by the DPPH radical scavenging and reducing power assays is reported in Table 2. The results showed that fresh pansies had higher values of antioxidant activity than crystallized pansies. During storage of crystallized pansies, statistically significant differences in the antioxidant activity were observed. An increase in the $\mathrm{EC}_{50} \mathrm{DPPH}$ value was detected between day 0 and 90 days (12.9-18.2 mg extract $/ \mathrm{ml}$ ), indicative of a decrease in the antioxidant power. A similar decrease was observed in DPPH (34.10 to $28.27 \%)$ and reducing power (48.08 to $40.26 \%$ ) assays for a pumpkin candy stored during 0-3 months (Muzzaffar et al., 2016). However, in the present work a slight decrease of $\mathrm{EC}_{50}$ reducing power values was observed ( 24.5 to $22.7 \mathrm{mg}$ extract $/ \mathrm{ml}$ for 0 and 90 days, respectively), suggesting a higher antioxidant activity.

Table 2. Total phenols, hydrolysable tannins, flavonoids, total monomeric anthocyanins, DPPH radical scavenging effect and reducing power in fresh and crystallized pansies during storage $(n=3)$.

\begin{tabular}{|c|c|c|c|c|c|c|c|}
\hline Samples & Storage & $\begin{array}{l}\text { TRC (mg } \\
\text { GAE/g dw) }\end{array}$ & $\begin{array}{l}\text { Total flavonoids } \\
\text { (mg QE/g dw) }\end{array}$ & $\begin{array}{l}\text { Hydrolysable } \\
\text { tannins (mg } \\
\text { TAE/g dw) }\end{array}$ & 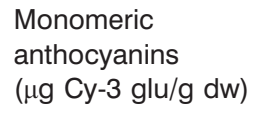 & $\begin{array}{l}\mathrm{EC}_{50} \mathrm{DPPH} \\
(\mathrm{mg} \text { extract } / \mathrm{ml})\end{array}$ & $\begin{array}{l}\mathrm{EC}_{50} \text { reducing } \\
\text { power }(\mathrm{mg} \\
\text { extract } / \mathrm{ml})\end{array}$ \\
\hline Fresh & 0 day & $5.43 \pm 1.25 b$ & $115 \pm 7.9 b$ & $52.3 \pm 10.0 \mathrm{~b}$ & $1016 \pm 30 d$ & $0.34 \pm 0.02 a$ & $6.60 \pm 0.24 a$ \\
\hline \multirow[t]{6}{*}{ Crystallized } & 0 day & $0.61 \pm 0.16 a, A$ & $4.11 \pm 0.72 \mathrm{a}, \mathrm{B}$ & $1.75 \pm 0.10 \mathrm{a}, \mathrm{A}$ & $40.3 \pm 12.7 a, A$ & $12.9 \pm 0.4 b, A$ & $24.5 \pm 0.4 f, F$ \\
\hline & 7 days & $0.60 \pm 0.05 a, A$ & $4.03 \pm 0.22 a, B$ & $3.13 \pm 0.61 a, B, C$ & $186 \pm 3 c, D$ & $18.7 \pm 1.0 \mathrm{~d}, \mathrm{e}, \mathrm{C}, \mathrm{D}$ & $19.8 \pm 0.1 c, d, C$ \\
\hline & 15 days & $0.64 \pm 0.03 a, A$ & $3.50 \pm 0.29 a, A$ & $2.64 \pm 0.52 a, B$ & $187 \pm 3 c, D$ & $16.1 \pm 0.5 \mathrm{c} . \mathrm{B}$ & $19.4 \pm 0.1 c, B$ \\
\hline & 30 days & $0.54 \pm 0.09 a, A$ & $2.08 \pm 0.08 a, A$ & $5.06 \pm 0.33 a, D$ & $196 \pm 15 c, D$ & $15.6 \pm 1.0 \mathrm{c}, \mathrm{B}$ & $16.3 \pm 0.2 b, A$ \\
\hline & 60 days & $0.62 \pm 0.06 a, A$ & $2.45 \pm 0.15 a, A$ & $4.39 \pm 0.66 a, D$ & $117 \pm 9 b, C$ & $19.7 \pm 0.1 e, D$ & $20.2 \pm 0.1 d, D$ \\
\hline & 90 days & $0.59 \pm 0.04 a, A$ & $1.94 \pm 0.04 a, A$ & $3.59 \pm 0.25 a, C$ & $100 \pm 2 b, B$ & $18.2 \pm 0.5 \mathrm{~d}, \mathrm{C}$ & $22.7 \pm 0.2 e, E$ \\
\hline
\end{tabular}

DPPH: 2,2-diphenyl-1-picrylhydrazyl; GAE: gallic acid equivalent; TAE: tannic acid equivalent; TRC: total reducing capacity. Values are expressed as mean \pm standard deviation. Lowercase letters compare all samples, while uppercase letters only compare crystallized pansies. Values with the same letter in the same column are not statistically different $(p>0.05)$. 
Table 3. Mean counts (log10 cfu/g \pm standard deviation) of total aerobic mesophilic microorganisms, yeasts, moulds, total coliforms, E. coli and psychrotrophic bacteria examined in fresh and crystallized pansies during storage for 0,7 and 90 days.

\begin{tabular}{|c|c|c|c|c|c|c|c|}
\hline \multicolumn{2}{|l|}{ Conditions } & \multirow[b]{2}{*}{$\begin{array}{l}\text { Total aerobic } \\
\text { mesophilic }\end{array}$} & \multirow[b]{2}{*}{ Yeasts } & \multirow[b]{2}{*}{ Moulds } & \multirow[b]{2}{*}{$\begin{array}{l}\text { Total } \\
\text { coliforms }\end{array}$} & \multirow[b]{2}{*}{ E. coli } & \multirow[b]{2}{*}{$\begin{array}{l}\text { Psychrotrophic } \\
\text { bacteria }\end{array}$} \\
\hline Samples & Time & & & & & & \\
\hline Fresh & 0 & $4.84 \pm 0.18 c$ & $5.95 \pm 0.03 b$ & $<2$ & $1.15 \pm 0.21 b$ & $<1$ & $<2$ \\
\hline \multirow[t]{2}{*}{ Crystallized } & 7 days & $4.34 \pm 0.10 \mathrm{~b}$ & $<2 a$ & $<2$ & $<1 \mathrm{a}$ & $<1$ & $<2$ \\
\hline & 90 days & $3.75 \pm 0.11 \mathrm{a}$ & $<2 a$ & $<2$ & $<1 a$ & $<1$ & $<2$ \\
\hline
\end{tabular}

Values with the same letter in the same column are not statistically different $(p>0.05)$.

\section{Microbial quality}

The total viable bacterial counts in fresh and crystallized samples (after 7 and 90 days) are shown in Table 3. From the results, it was found that the bacterial load in crystallized pansies was lower than in fresh samples, and it decreased along storage.

Particularly, fresh pansies presented higher values of yeast $(5.95 \log \mathrm{cfu} / \mathrm{g})$, total coliforms $(1.15 \log \mathrm{cfu} / \mathrm{g})$ and total aerobic mesophilic microorganisms (4.84 log cfu/g) than crystallized samples; however, it should be noted that the values determined for fresh pansies are still acceptable, taking into account the established limits for salads and vegetables group (Santos et al., 2005).

Furthermore, crystallized samples stored for seven days showed higher values of total aerobic mesophilic microorganisms than stored for 90 days (4.34 and $3.75 \log \mathrm{cfu} / \mathrm{g}$, respectively). This decrease was probably due to the sugar added to pansies that bound the water and reduced the amount of water available for the growth of microorganisms. So, they could not multiply and cause food spoilage (Hasanuzzaman et al., 2014; Muzzaffar et al., 2016), with crystallized pansies remaining safe for human consumption during three months of storage.

\section{CONCLUSION}

In summary, pansies subjected to crystallization showed good appearance for 90 days of storage. However, significant differences in the nutritional composition, bioactive compound contents and antioxidant activity were detected between fresh and crystallized pansies. During storage, pansies showed a decrease in moisture, ash and protein contents, as well as flavonoids and monomeric anthocyanins. On the contrary, hydrolysable tannins increased. Furthermore, crystallized pansies had lower microorganism counts than fresh samples. So, crystallization method not only improved the shelf-life of pansies but also improved their microbial quality.

\section{DECLARATION OF CONFLICTING INTERESTS}

The author(s) declared no potential conflicts of interest with respect to the research, authorship, and/or publication of this article.

\section{FUNDING}

The author(s) disclosed receipt of the following financial support for the research, authorship, and/or publication of this article: The authors acknowledge the Portuguese Foundation for Science and Technology (FCT, Portugal) for the financial support provided by the research grant (SFRH/BD/95853/ 2013), QOPNA research Unit (FCT UID/QUI/00062/2013), REQUIMTE (PEst/UID/QUI/50006/2013) and 'Project [NORTE-07-0124-FEDER-000069]' and CIMO (UID/ AGR/00690/2013), through national funds and when applicable co-financed by the FEDER, within the PT2020 Partnership Agreement.

\section{REFERENCES}

AOAC. (1990). Association of Official Analytical Chemists, 15th ed. Washington, DC: Official Method of Analysis.

Barat JM, Talens P, Barrera C, Chiralt A and Fito P. (2002). Pineapple candying at mild temperature by applying vacuum impregnation. Journal of Food Science 67(8): 3046-3052.

Clemons J. (2006). Non-perishable plant-derived decorative items and methods for making same. Patent 20060172042 A1, USA.

Creasy R. (2012). Candied flowers. In: Periplus Editions (eds) Edible Flower Garden. Hong Kong: Tuttle Publishing, pp. $72-74$.

Delgado T, Malheiro R, Pereira JA and Ramalhosa E. (2010). Hazelnut (Corylus avellana L.) kernels as a source of antioxidants and their potential in relation to other nuts. Industrial Crops and Products 32: 621-626.

Dupree N. (2004). Ladies' lunches. In: Krauss P. (eds) Nathalie Dupree's Southern Memories: Recipes and Reminiscence. Georgia: The University of Georgia Press, p. 17.

Falcão A, Chaves ES, Kuskoski EM, Fett R, Falcão LD and Bordignon-Luiz MT. (2017). Total polyphenol index, total anthocyanins and antioxidant activity of a model system 
of grape jelly. Ciência e Tecnologia de Alimentos 27: 637-642.

Fernandes L, Casal S, Pereira JA, Pereira EL, Ramalhosa E and Saraiva JA. (2017). Effect of high hydrostatic pressure on the quality of four edible flowers: Viola $\times$ wittrockiana, Centaurea cyanus, Borago officinalis and Camellia japonica. Food Science and Technology International 52(11): 2455-2461.

Fernandes L, Casal S, Pereira JA, Pereira EL, Saraiva JA and Ramalhosa E. (2018). Effect of alginate coating on the physico-chemical and microbial quality of pansies $($ Viola $\times$ wittrockiana) during storage. Food Science and Biotechnology 27(4): 987-996.

González-Barrio R, Periago MJ, Luna-Recio C, Javier G-AF and Navarro-González I. (2018). Chemical composition of the edible flowers, pansy (Viola wittrockiana) and snapdragon (Antirrhinum majus) as new sources of bioactive compounds. Food Chemistry 252: 373-380.

Hasanuzzaman Md, Kamruzzaman M, Islam MMd, Khanom SAA, Rahman MdM, Lisa LA, et al. (2014). A study on tomato candy prepared by dehydration technique using different sugar solutions. Food and Nutrition Sciences 5: 1261-1271.

Kim DO and Padilla-Zakour OI. (2004). Jam processing effect on phenolics and antioxidant capacity in anthocyanin-rich fruits: Cherry, plum, and raspberry. Journal of Food Science 69: 395-400.

Korel F and Balaban OM. (2006). Composition, color and mechanical characteristics of pretreated candied chestnuts. International Journal of Food Properties 9: 559-572.

Li A-N, Li S, Li H-B, Xu D-P, Xu X-R and Chen F. (2014). Total phenolic contents and antioxidant capacities of 51 edible and wild flowers. Journal of Functional Foods 6: 319-330.

McGee H. (2010). Sugars, syrups and candies. In: Kindle Edition (eds) Keys to Good Cooking: A Guide to Making the Best of Foods and Recipes. London: Hodder \& Stoughton, p. 23.

Muzzaffar S, Baba WN, Nazir N, Masoodi FA, Bhat MM and Bazaz R. (2016). Effect of storage on physicochemical, microbial and antioxidant properties of pumpkin (Cucurbita moschata) candy. Food Science \& Technology 2: $2-13$.

Nunes C, Coimbra MA, Saraiva J and Rocha SM. (2008). Study of the volatile components of a candied plum and estimation of their contribution to the aroma. Food Chemistry 111: 897-905.

Rop O, Mlcek J, Jurikova T, Neugebauerova J and Vabkova J. (2012). Edible flowers - A new promising source of mineral elements in human nutrition. Molecules 17: 6672-6683.

Santos MI, Correia C, Cunha MIC, Saraiva MMM and Novais R. (2005). Valores Guia para avaliação da qualidade microbiológica de alimentos prontos a comer preparados em estabelecimentos de restauração. Instituto Nacional de Saúde Dr. Ricardo Jorge - INSA; Centro de Segurança Alimentar e Nutrição - CSAN. Revista da Ordem dos Farmacêuticos 64: 66-68.

Sotelo A, López-García S and Basurto-Peña F. (2007). Content of nutrient and antinutrient in edible flowers of wild plants in Mexico. Plant Foods for Human Nutrition 62: $133-138$.

Varela-Santos E, Ochoa-Martinez A, Tabilo-Munizaga G, Reyes JE, Pérez-Won M, Briones-Labarca V, et al. (2012). Effect of high hydrostatic pressure (HHP) processing on physicochemical properties, bioactive compounds and shelf-life of pomegranate juice. Innovative Food Science and Emerging Technologies 13: 13-22.

Witczak T, Witczak M, Socha R, Stepien A and Grzesik M. (2017). Candied orange peel produced in solutions with various sugar compositions: Sugar composition and sorption properties of the product. Journal of Food Process Engineering 40: 1-12. 